\title{
Direct Application of WTO Rules By China People's Court in PRC Law
}

\author{
Keshu $\mathrm{Li}^{1,} \mathrm{a}^{*}$, Meixia Shi ${ }^{2, \mathrm{~b}}$ \\ 1. Management,Beijing Jiaotong University, Beijing,China \\ 2. Management of Beijing Jiaotong University, Beijing,China \\ alks1326@163.com, bsammarsyang@sina.com
}

\begin{abstract}
Keywords: Direct applicability of WTO rules, direct effect of WTO rules, the European Court of Justice, EU law, China People's Court.
\end{abstract}

\begin{abstract}
Nowadays, the world is changing rapidly through the economic globalization. World Trade Organization (WTO) plays the most important role. In this article, I will focus on how China People's Court can deal with WTO rules. I support that China People's Court should grant direct effect of WTO rules in PRC law.
\end{abstract}

\section{Direct Applicability of WTO Rules}

With respecting to direct applicability, Josephine Steiner \& Lorna Woods said, "With the passing of this Act all Community law became, in the language of international law, directly applicable, that is, applicable as part of our own internal system." ${ }^{1}$, from here we can understand what the direct applicability is, that is, applying the international law as a part of the country's own internal system. In other words, the provisions of the international law can be capable of application by national courts.

However, the direct effect which means that the international law has same legal status of domestic law is different. Although people use them interchangeably, direct effect and direct applicable are similar but there are different ${ }^{2}$. The relationship may describe as follows: "Not all provisions of directly applicable international law are capable of direct effect ......Direct applicability is a necessary precondition for direct effects.” ${ }^{3}$

\section{Direct Application of WTO Rules By China People's Court in PRC Law}

Based on all the analysis and arguments I mentioned in the previous parts, I strongly keep the opinion that ECJ should grant direct effect of WTO rules in EU law. As a Chinese, I also consider the choice of Chinese Court.

In order to make China more familiar with international trade rules and get more benefits from world free trade, Chinese Court also needs to grant direct effect of WTO rules in EU law, because China has the advantage as "world factory".

\subsection{The current states of International treaties in Chinese domestic law}

Before discussing the application of WTO rules in the Chinese court, we need to view the attitude of Chinese Court to the international treaties; it means that we must understand the status of international treaties in Chinese domestic laws. How China fulfills its treaty obligations.

The status of treaties in domestic laws is that, how a country deals with the reciprocity and conflicts between treaties and its domestic laws. In this aspect, different countries have different practices.

In the Chinese legal system, as the national fundamental law and most important law, the Constitution of the People's Republic of China has the supremacy in the system. Therefore, the

\footnotetext{
1 Josephine Steiner \& Lorna Woods, Textbook on EC Law: Text, Cases, and Materials, (6 $\left.{ }^{\text {th }}, 1998\right)$, Blackstone Press Limited, P45

2 As this book mentions, "the terms 'direct applicability" and 'direct effect "have been used interchangeably by ECJ, yet they are separate concepts.” , <European Union Law> (translation), Wuhan University Press, 2003, first edition,P50

${ }^{3}$ See supra note 18, P46.
} 
Constitution is above the international treaties. The Constitution does not directly set out the relations between treaties and domestic laws. However, we may see the relationships from the legal provisions relating to adoption of a treaty. In China, the approval of treaties and important agreements are decided by the Standing Committee of the National People's Congress, and general legislations, for example, those relating to criminal acts or civil basic law, are also approved by the National People's Congress or its Standing Committee.4 Thus, the legal states of them are equal.

Legislations in Chinese domestic law can divide into three types according to their contents:

(a) The provisions of the treaty are applicable if the domestic laws have different stipulation from that of the treaty signed by China, except the provisions that China has declared to reserve. An example is the 1991 "People's Republic of China Civil Procedure Law" Article 238 and so on.

(b) The domestic laws directly provide that specific provisions of the treaties that China has participated in are applicable in relevant matters. For example, in 1995 Revised Chinese Trademark Law, Article 3 Implementation Regulation stipulates, "international trademark registration shall be handled according to the Madrid Agreement Concerning the International Registration of Marks"

(c) The domestic laws provide that a specific item is to be handled according to a specific law, but when the international conventions that China has joined have other provisions, the international conventions should be complied with; or where the domestic laws do not address the matter completely, the matter should be handled according to the related treaty. For example, Article 2 of the 1996 Chinese Civil Aviation Safety and Security Rule, Article 23 of the Usage of the Emblem of the Chinese Red Cross.

In principle, the treaties and agreements, which have explicitly stipulated by domestic legislative procedure to be directly applicable, have the efficacy to be applied directly in the Chinese court.

\subsection{The current states of WTO agreements in Chinese domestic law and possible way to direct application WTO agreements in Chinese domestic law}

\subsubsection{The current states of WTO agreements in Chinese domestic law}

In 2001, China formally joined WTO as a member states after 11 years' efforts of China. China's accession to the World Trade Organization (WTO) is an important event in the advancement of China's reform and open policy. Considering the huge population of China as well as its important status in the world trade domain ${ }^{5}$, the attitude of Chinese Court about direct effect of WTO rules has the very important influence in other member states of WTO Courts.

After China's accession to the WTO, the investors or trade businessmen are mostly concerned with the status of the WTO rules in the Chinese domestic laws, that is to say, how China fulfills its treaty obligations, whether the WTO rules can be directly applicable before the Chinese court or not. It directly related the individual rights for investment and trade.

It is surprised that , WTO rules still not applied directly in the Chinese court, and the main basis supporting this conclusion is the Rules of the Supreme People's Court concerning Certain Questions in Trying International Trade Administration Cases6, where Article 9 of the Rules set out:

"...the court shall apply the explanation that is consistent with the provisions related to the international conventions, except for those that have been declared to reserve by the People's Republic of China." 7

Obviously, the Chinese court does not propose or carry out direct application of WTO rules in the judicial system. Through revising and formulating domestic laws, China transforms and implements the WTO rules and fulfils its commitment of accession to the WTO. The former Vice

\footnotetext{
${ }^{4}$ See Articles 67(14), 62(3), 64 and 67(2) of the Constitution of the People's Republic of China (1982).

${ }^{5}$ Besides, until 2007, the economy of the People's Republic of China is the fourth largest in the world when measured by nominal GDP.

${ }^{6}$ On 27 August 2002, the 1239th meeting of the Judicial Commission of Supreme People's Court passed to start implementation on 1 October 2002. The Rules were the first judicial explanation on the principles of the Supreme People's Court in deciding cases related to international trade administration concerning the WTO rules, and it examines the Supreme People's Court's judicial responsibility according to the domestic laws undertaking the WTO rules and requirement of the China's accession to the WTO. This set of rule will have a significant and profound influence.

${ }^{7}$ Unofficial translation of original text
} 
President of the Supreme People's Court of PRC, Li Guoguang, stated that, the principle that Chinese court cannot apply WTO rules directly has two meanings:

"First, individuals and the enterprises cannot apply WTO rules directly to bring a lawsuit or raise a defence in court. Second, the court cannot cite WTO rules directly in its decisions as grounds of judgement." 8

However, we should notice that WTO agreements still have great effect in indirectly way. Since China acceded to WTO in 2001, China has changed thousands of laws and regulations to match the rules of WTO agreements, which are the promises that made by Chinese Government. ${ }^{9}$

2.2.2 Possible way to direct application WTO agreements in Chinese domestic law

In my opinion, based on the same arguments that I did to support the direct effect of WTO agreements in EU law . Besides one of the principles of application of international legal rules in Chinese law is that if there is conflict between international legal rules and Chinese domestic law, international legal rules will prevail, Chinese court should grant direct effect in Chinese court.

Considering the judicial system in China, my suggestions are as follows:

(a) At first, considering the legal effect, the Standing Committee of the National People's Congress of China should discuss and pass the legislation or decision that WTO rules have direct. Only using this way can WTO rules be really direct applicable in Chinese courts. Because only the law which passed by National People's Congress or the Standing Committee of the National People's Congress of China is the most important law and it has the strongest effect.

(b) To consider the difference between ability and knowledge of the judges among the different ranks at Court, I suggest that: only the Intermediate People's Court and above (Advanced People's Court and Supreme People's Court) have the right to deal with the case related to WTO rules because the case related to WTO rules are comparatively complicated. If the law also allows the basic people's court to deal with those cases, it cannot guarantee the quality and the exactness of the judgments, which is a risk for the Chinese legal order.

(c) In case, there are some conflicts between WTO rules and Chinese domestic law, if WTO rules conflict with the Constitution of the People's Republic of China the Constitution of the People's Republic of China will prevail definitely. If WTO rules conflict with Chinese domestic basic law, such as Chinese criminal law and civil law, then Chinese Court should have the judgments case by case. However, if WTO rules conflict with the Chinese domestic law that lower than the Constitution and basic law, then WTO rules should prevail.

(d) Finally, considering the complexity of WTO rules, the Supreme People's Court of China should have the final rights to give the judgment and explain the issues related to how to implement the WTO rules when there are some cases with the problems that the Chinese low-ranking court cannot solve.

\section{References}

[1] J. Steiner, L. Woods, Textbook on EC Law: Text, Cases, and Materials, Blackstone Press Limited, 6th, 1998,P45

[2] J. Steiner, L. Woods, Textbook on EC Law: Text, Cases, and Materials, Blackstone Press Limited, 6th, 1998, P45

[3] Case C - 53/ 96 , Hermès international v. FHT Marketing Choice BV, [1998] ECR I -3603

[4] Article 12 of the Treaty establishing the European Community

[5] Case C-183/95 Aftish BV v Rijksdienst voor de keuring van Vee en Vlees,[1 997]ECR I-4315

[6] Joint cases C 364/ 95 and C - 365/ 95 ,T.Port GmbH \& Co. v

\footnotetext{
${ }^{8}$ http://www.southcn.com/news/china/important/200208291519.htm, last visit on 28 April 2007.

9 The details of data are available on http://news.xinhuanet.com/fortune/2006-12/10/content_5465184.htm , last visited on 27, April, 2007
} 
[7] Case C - 100/ 96 ,Queen v. Ministry of Agriculture , Fisheries and Food ,ex parte British Agrochemicals

[8] Case T - 254/ 97 Eruchthandelsgesellschaft mbH Chemnitz v Commission, [1999]3 C. M. L. R. 508

[9] Case C-104/97, P Atlanta v European Community, [1999] ECR I-6983

[10]Case T-174/00, Biret International SA v Council of the European Union [2002], ECR II -17 and Case T-210/00, Establishments Biret et Cie. SA v Council of the European Union [2001],ECR II-47.

[11]Case C-70/88, Parliament v. Council (Chernobyl)[1990], E.C.R. I-2041, I-2073.

[12]Case 12/86, Demirel v. Stadt Schwäbisch Gmünd [1987], E.C.R. 3747, 3752

[13]Case 12/86, Demirel v. Stadt Schwäbisch Gmünd [1987], E.C.R. 3747, 3752

[14]Case 17/81, Pabst \& Richarz KG v. Hauptzollamt Oldenbourg , [1982], ECR 1331

[15]Case C-192/89, S.Z. Sevince v. Staatssecretaris van Justitie, 1990 ECR 346

[16]Case C-18/90, Office National de l'Emploi v. Bahia Kziber, 1991 ECR 199.

[17]Case C-432/92 ,The Queen v Minister of Agriculture, Fisheries and Food, ex parte SP Anastasiou (Pissouri) Ltd and Others [1994], ECR I-3087

[18]<European Union Law> (translation), Wuhan University Press, 2003, first edition,P2

[19]J.O. Berkey, “The European Court of Justice and Direct Effect for the GATT: A Question Worth Revisiting,” European Journal of International Law,1998,9(4) 9, pp. 640

[20]J. Pieter, Kuijper, The new WTO dispute settlement system-the impact on the European Committee. Journal of World Trade, Issue6, pp49-71

[21]P. Lee and B. Kennedy, The potential Direct Effect of GATT 1994 in European Community law , Journal of World Trade, 1996, 30 (1):67-89

[22]J. Pieter, Kuijper, “The Conclusion and Implementation of the Uruguay Round Results by the European Community” ,European Journal of International Law, 6(1),January1995

[23]M. Hilf, The ECJ's Opinion 1/94 on the WTO- No Surprise, but Wise?, European Journal of International Law, 6(2),January1995,

[24]K. Jan, Kuilwijk, “The European Court of Justice and the GATT Dilemma: Public Interest versus Individual Rights?” 12 January(1996),p341

[25]G. Zonnekeyn, EC Liability for the Non-Implementation of WTO Dispute Settlement Decisions-- Advocate General Alber Proposes a 'Copernican Innovation' in the Case Law of the ECJ, Social Science Electronic Publishing 7.2(2008),pp:483-490 